\title{
Corporate Social Responsibility and the Pricing of Seasoned Equity Offerings: Does Executive Firm-Related Wealth Matter?
}

\author{
Hong Chuong PHAM${ }^{1}$, Duc Anh NGO², Ha Thanh LE ${ }^{3}$, Thiet Thanh NGUYEN ${ }^{4}$
}

Received: June 03, 2020 Revised: June 28, 2020 Accepted: July 09, 2020

\begin{abstract}
This study exemines the roles of corporate social activity (CSR) and executive compensation structure on the pricing of seasoned equity offerings (SEOs) with special focus on the role of CSR in reducing the level of information asymmetry between managers and future shareholders of issuing firms through SEOs. This study also investigates the interaction between executive compensation structure and CSR on the discounting of SEOs. We use a sample of 2,102 seasoned equity offerings of U.S. firms with CSR scores from 1995 to 2015 in our OLS fixed effect regression analysis. The results show that issuing firms with high CSR are more likely to expericence a lower degree of the SEO discount. The results also document a positive association between CSR and a high proportion of equity-based compensation of issuing firms' executives. The findings of this paper confirm that CSR attenuates the impact of information asymmetry and the pre-SEO price uncertainty on the pricing of the offers and hence the SEO discount. Furthermore, CSR reinforces the impact of executive firmrelated wealth on the discounting of seasoned equity offerings. It appears that firm-related wealth motivates managers to actively engage in reducing information asymmetry activities before SEOs, thereby decreasing the SEO discount.
\end{abstract}

Keywords: Corporate Social Responsibility, Seasoned Equity Offerings, Executive Compensation Structure, Firm-Related Wealth

JEL Classification Code: G32, G34, G15

\section{Introduction}

Corporate social activity (CSR) can bring different types of benefits to a firm's stakeholders in several ways including

${ }^{1}$ First Author. Associate Professor, University Management Board, National Economics University, Vietnam. Email: chuongph@neu.edu.vn

${ }^{2}$ Associate Professor, Department of Accounting, Finance and MIS, School of Business, Norfolk State University, U.S.A. Email: adngo@nsu.edu

${ }^{3}$ Corresponding Author. Associate Professor, Faculty of Environment, Climate Change and Urban Studies, National Economics University, Vietnam [Postal Address: 207 Giai Phong Road, Dong Tam Ward, Hai Ba Trung District, Hanoi, 113068, Vietnam] Email: thanhlh@neu.edu.vn

${ }^{4}$ Assistant Professor, Accounting, Economics, and Finance Department, George Dean Johnson Jr. College of Business and Economics, University of South Carolina Upstate, U.S.A. Email: tnguyen2@uscupstate.edu

(c) Copyright: The Author(s)

This is an Open Access article distributed under the terms of the Creative Commons Attribution Non-Commercial License (http://Creativecommons.org/licenses/by-nc/4.0/) which permits unrestricted noncommercial use, distribution, and reproduction in any medium, provided the original work is properly cited. better brand recognition, increased customer base, and brand loyalty, easier access to the capital markets, and positive market reactions to its major economic event announcements. For example, Lins et al. (2017) find evidence that increased spending on CSR improves the trust between CSR firms and investors, especially during a period when the overall trust in corporations and markets is low. They show that firms with high CSR activities have stock returns four to seven percent higher than firms with low CSR activities. Zahari et al. (2020) many companies have embraced corporate social responsibility (CSR examine the relationship between CRS practices and brand equity among the top 100 brands in Malaysia and find that CRS pratices improve financial-based brand significantly.

Edmans (2011 and 2.1\% above industry benchmarks. The results are robust to controls for firm characteristics, different weighting methodologies, and the removal of outliers. The Best Companies also exhibited significantly more positive earnings surprises and announcement returns. These findings have three main implications. First, consistent with human capital-centered theories of the firm, employee satisfaction is positively correlated with shareholder returns and need not represent managerial slack. Second, the stock market does 
not fully value intangibles, even when independently verified by a highly public survey on large firms. Third, certain socially responsible investing (SRI) analyses the relationship between employee satisfaction and long-run stock returns and finds that the stock performance of high CSR firms outperforms that of their industry benchmarks. The author also finds that investing in CSR helps firms improve their investment returns. Similarly, Yang and Kim (2018) conduct a survey of South Korean corprorates' employees to evaluate the effects of CSR activities on employee work performance. The authors find CSR not only enhances work performance but also promotes firms' authentic leadership. Over the last two decades, an increasing number of firms engage in CSR activities not only to meet new regulation requirements but also to reduce the pressure of investor activism requiring firms to consider the interest of broader stakeholders such as communities, employees, and environmental groups. However, managers may tend to take advantage of a positive market response to firms' CRS activities to opportunistically increase their wealth rather than increase their shareholders' wealth, especially during periods surrounding firm major economic event announcements.

According to the pecking order theory of capital structure, managers follow a hierarchy order of financing sources. Managers prefer retained earnings to debt, and debt to new equity issues when financing their new projects. For example, Myers and Majluf (1984) show in their model that managers only issue new equity when they believe their stocks are overvalued to increase the current shareholders' wealth at the expense of new shareholders. Outside investors, who do not possess the same level of inside information as the managers do, yet understand the motivation of managers, react negatively to firms' announcements of seasoned equity offerings. Corwin (2002) provides evidence that new equity offers are underpriced by 2.2 percent in the sample of firms issuing seasoned equity offerings during the 1980s-1990s periods. That means, on average, the closing price on the offer day of the issuing firm is about 2.2 percent less than the offer price of new equity. In a similar study on the discounting and clustering in seasoned equity offerings, Mola and Loughran (2004) examine a sample of 4,814 SEOs from 1986-1999 and find that, on average, the new offers are priced at a discount of more than 3.0 percent. The discounting of SEOs reflects in part the rounding practices for new offers as well as the underwriters' rent extraction ability.

If CSR can increases firms' reputation in financial markets, CSR also can mitigate the negative market reactions to firms' announcements of seasoned equity offerings. Recently, Feng et al. (2018) examine whether CSR can add value to capital market participants through seasoned equity offerings and find that CSR issuing firms experience a lesser degree of negative reactions to SEO announcements partly because CSR helps reduce information asymmetry between managers and outside investors. Similarly, Yoon and Lee (2019) examine how CSR is related to the degree of asymetric information in the Korean financial market. They find that firms with high CSR scores are associated with a lower level of information asymetry. Howevey, the authors find no evidence of such relation in the sample of cheabolaffiliated firms. Follow this line of logic, in this study we investigate whether managers' firm related wealth from their compensation packages play a significant role in the pricing of new offers as well as in increasing CSR activities before seasoned equity offerings, thereby reducing the level of SEO discount.

We focus on examining the relationship between managers' firm-related wealth and SEO discount for two reasons. First, according to agency theory, managers always consider maximizing their compensation or their firm related wealth in any corporate decision. Consequently, managers are more likely to opportunistically increase spending on CSR activities before any corporate event that may negatively impact on both their short term compensation such as salaries or bonus vested shares and long-term firm related wealth compensation such as the value of stock options or unvested shares. Second, as Carlson et al. (2010) already find in their study that the firm risk changes dynamically around seasoned equity offerings which often creases before SEOs and decreases gradually thereafter, it's likely that managers who have a large proportion of payfor-performance compensation such as restricted stocks or stock options in their compensation packages are conscious about their wealth. Therefore, managers not only try to reduce information asymmetry by increasing spending on CSR activities before SEOs but also carefully work with underwriters to have better offer prices for their new offers, thereby maximizing their firm related wealth through their firms' SEO episodes.

To our best of our current knowledge, this is the first study to examine the combined effects of CSR and executive compensation structure on the pricing of seasoned equity offerings. We shed new light on how the structure of executive compensation impacts, coupled with the effects of the managers' opportunistic decisions regarding CSR activities, on the pricing of seasoned equity offerings by investigating the SEO discount level. We find that outside markets respond positively to new offers of issuing firms with high CSR activities. In addition, issuing firms with top executives having a larger proportion of firm related wealth in their compensation packages experience a lesser degree of SEO discounts. Specifically, the results show that managers' firm related wealth is associated with a higher level of CSR activities and a lower level of SEO discount. Our findings suggest that managers may mitigate the effects of negative market response to SEO announcements by engaging CSR activities before the SEO episodes as well as 
by carefully timing and pricing their new offers to maximize their wealth.

The paper proceeds as follows. The next section presents a brief literature review and hypothesis development. Section 3 describes the sample and methodology. Section 4 reports and discusses the results. Section 5 sets out to conclude the paper.

\section{Literature Review and Hypotheses}

Agency theory provides a framework that explains and resolves conflicts between an agent and a principal that can occur in a situation in which the goals or desires of both sides differ. To mitigate agency problems, the principal may design a contract that aligns the agent's interests with the principal's interests. In terms of compensation structure, the principal usually offers a compensation package that ties the agent's compensation with firm performance based on some performance measures such as profitability or stock price since it is difficult or expensive for the principal to verify or observe the actual efforts of the agent. However, no compensation contract is perfect, and therefore managers can always find a way to maximize their wealth regardless of whether it is at the expense of shareholders. In a seminal paper of agency theory, Jensen (1986) provides a detailed analysis of why a manager in a public firm chooses a set of activities for the firms such that the total value of the firm is less than it would be if the manager is a sole owner of the firm.

Our research is at the intersection of agency problems and external financing literature. In a new share issue, current shareholders' wealth can be affected negatively or positively by the new issue depending on the offer price of the new shares greater or lesser than the current trading price. Datta et al. (2005) use a sample of 444 U.S. SEOs during the period 1995-1999 and find that there is an adverse stock price effect for issuing firms with high executive equity based compensation. Their findings also suggest that one of important determinants of the shareholders wealth effects associated with new equity offerings is the structure of executive compensation. In a similar study, Brazel and Webb (2006) investigate the effect of executive compensation on the short-term market reactions following SEO announcements and find that investors are more likely to negatively react to the SEO announcements of firms whose managers are paid with a high proportion of performance based incentives. More recently, Brisker et al. (2014) examine the executive compensation structure and motivations of seasoned equity offerings and find that managers who are awarded high equity-based compensation are more likely to time their seasoned equity offerings to periods when their firms' stocks are overvalued to maximize their compensation.
We extent their findings by examining the interaction effect of executive compensation structure and CSR activities on the pricing of seasoned equity offerings. If markets react positively to new seasoned equity offerings issued by high CSR firms, post-issue market performance of high CSR firms would outperform that of low CSR firms. In addition, the managers of the issuing firms with a high firm related wealth are more likely to price their new offers at a lesser discount degree compared with those of issuing firms with a smaller firm related wealth. Taken together, our first hypothesis as follows:

H1A: The post-SEO stock performance of issuing firms with high CSR scores is better than that of issuing firms with low CSR scores.

H1B: The post-SEO stock performance of issuing firms with managers having a relatively high proportion of equitybased compensation is higher than that of issuing firms with a relatively low proportion of equity-based compensation.

The previous studies (i.e., Jensen \& Meckling, 1976; Myers \& Majluf, 1984; Mola \& Loughran, 2004) provide a theoretical foundation and an empirical strategy for our research. According to Myers and Majluf (1984), firms do not have optimal debt-equity ratios. Instead, they follow the pecking order when raising external capital for their financing needs to minimize their financing costs. Because of information asymmetry between managers and outside investors, to reduce financing cots managers only depends on the equity market if they exhaust all retained earnings and their debt financing becomes prohibitively expensive. In other words, managers only issue new equity, if other sources of financing such as retained earnings or debt available, when they believe their stock is overvalued to maximize current shareholders' wealth at the expense of future shareholders. In case managers have to turn to the equity market for their financing needs, they can mitigate negative market reactions to their new offerings by opportunistically timing their offerings to have a better price for their new shares. Mola and Loughran (2004) finds evidence that investment banks can extract rents from issuing firms by discounting new equity offers to maximize their profit. Their study shows that issuing firms allowing a discount on their new issues because issuing firms consider analyst coverage very important to their success of new equity offerings.

A few investment bankers or underwriters with highly regarding research analysts provide underwriting services in the market, therefore they have a strong influence on setting prices for new offers of issuing firms. Also, SEO discounts reflect the cost of uncertainty about firm value, marketing cots about new issues, and acquiring information that raises the offer price (Altinkiliç \& Hansen, 2003; Mola 
\& Loughran, 2004). We expect that managers with high equity compensation have a concern for a discount level of their new offerings because their compensation value is tied with firm performance and stock prices, and this concern motivates them to actively engage in pricing of seasoned equity offerings as well as opportunistically increase their level of CSR activities before SEO announcements to mitigate the impacts on their firm-related wealth after SEOs due to negative market reaction. We, therefore, offer our second hypothesis as follows:

H2A: The SEO discount of issuing firms with high CSR is lower than that of issuing firms with low CSR.

H2B: The SEO discount of issuing firms with managers having a relatively high proportion of equity-based compensation (firm-related wealth) is lower that of issuing firms with managers having a relatively low proportion of equity-based compensation (firm-related wealth).

\section{Data and Research Methods}

\subsection{Data Sources}

In this study, we use data from several sources for empirical analysis. We begin with a sample of all U.S firms conducting SEOs from 1991 to 2015 from the SDC Platinum's New Issues Database. We obtain only U.S. common equity offers after excluding private placements, right offers, and unit investment trusts offers. We choose the sample period from 1991 to 2015 because we can match the SEO sample with CSR information from the MSCI ESG KLD Stats dataset. The MSCI ESG KLD Stat initially provided corporate social responsibility ratings of 650 firms that comprise the S\&P 500 and the FTSE KLD 400 Social Index in 1991. The dataset expanded the coverage to the 1,000 and the 3,000 largest publicly traded U.S companies in 2001 and 2003 respectively. The KLD dataset covers approximately 80 indicators in corporate social responsibility areas including community, corporate governance, diversity, employee relations, environment, human rights, and product. This dataset also provides information for involvement in controversial business issues or in "sin businesses" such as alcohol gambling, firearms, military, nuclear power, and tobacco. We extract accounting data and stock prices from the Compustat and CRSP datasets to construct our dependent and control variables in our regression analysis. The sample selection process is presented in Table 2 Panel A.

First, we obtain a sample of 3,070 SEOs of non-financial and utilities U.S. firms from 1991 to 2015. We then match the SEO sample to the KDL database to obtain CSR information for the SEO sample. The matching process reduces our SEO sample with CSR information to 2,492 observations. We obtain underwriters' ranking information for the SEO sample from Prof. Ritter's underwriter database. We obtain financial information and stock prices from COMPUSTAT and CRSP databases to compute our independent variables. We drop all observations with insufficient data to calculate the stock price volatility, firm beta, market-to-book, IPO underpricing, and underwriters' ranks.

The sample for regression analysis of SEO discount (Model 1) in Table 5 has 2,102 observations. We then collect executive compensation data from the Standard and Poor's ExecuComp database. We also use the ExecuComp database to compute the annual aggregated firm-related wealth of all top executives in a given firm for the entire sample. Firmrelated wealth is the sum of the value of stock and options portfolios held by an executive. We also use executive compensation information to construct two variables of interest, namely DELTA and VEGA, which are proxied for the executive performanc-pay sensitivity to the firm's stock prices and the firm's stock returns, respectively. Our final sample for analysis of the effects of executive firm-related wealth on post SEO stock performance has 978 observations.

\subsection{Regression Models and Variable Construction}

To test the effects of corporate social activity and executive compensation structure on the post-SEO stock performance, our main dependent variables are CAR (the cumulative abnormal stock returns five trading days after the SEO announcement date $(C A R[0:+5])$. We use the market model to estimate $C A R$ after the announcement date for each SEO during the sample period.

Our main independent variables of interest are the total corporate social responsibility (TCSR) and the aggregate executive firm-related wealth (INSIDEWEALTH). We follow previous studies (e.g. Chatterji et al., 2009; Kim et al., 2012) to construct two versions of our corporate social responsibility variable. The first version (TCSRl) is the total number of strength indicators minus the total number of concern indicators aggregated across five social rating categories including community, diversity, employee relations, environment, and product for each firm in a given year. In a similar vein, we construct the second version (TCSR2) by aggregating the net CSR scores by taking the total number of strengths minus the total number of concerns in each category but excluding the corporate governance category to disentangle the effect of CSR and corporate governance. We follow Sundaram and Yermack (2007) to calculate executive firm-related wealth (INSIDEWEALTH). The executive firm-related wealth equals the market value of equity owned by all top firm's executives reported in Execucomp database plus the value of options held. The value of option portfolios is estimated based on the BlackScholes option valuation model. 
In our robustness tests, we follow Core and Guay (2002) to construct our two additional variables proxied for the sensitivity of executive compensation to stock prices (DELTA) and the sensitivity of compensation to stock return volatility (VEGA). DELTA is the change in the aggregate value of options held by the firm's all top executives for one percent change in the stock price and $V E G A$ is the change in the aggregate value of options held by the firm's all top executives associated with one percent change in the annualized standard deviation of stock return. We use the Black and Scholes (1973) model formula for valuing European call options to estimate DELTA and VEGA for each executive annually.

Option Value $=\left[S e^{-d T} N(Z)-X e^{-r T} N\left(Z-\delta T^{\left(\frac{1}{2}\right)}\right]\right.$

Where $Z=\left[\operatorname{Ln}\left(\frac{S}{X}\right)+T\left(r-d+\frac{\delta^{2}}{2}\right)\right] / \delta T^{\left(\frac{1}{2}\right)}$

$\mathrm{N}$ : Comulative probability function for the normal distribution

S: Price of the underlying stock

$\mathrm{X}$ : Strike price of the option

$\delta$ : Expected stock return volatility over the life of the option

r: Natural logarithm of risk-free rate

T: Time to maturity of the option in years.

D: Natural logarithm of the expected dividend yield over the life of the option

The values of DELTA and VEGA are calculated as follows:

DELTA $=[\Delta(\text { option value }) / \Delta(\text { price })]^{*}($ price $/ 100)$

$$
=e^{-d T} N(Z) *\left(\frac{\text { price }}{100}\right)
$$

$\mathrm{VEGA}=[\Delta(\text { option value }) / \Delta(\text { stock volatility })]^{*} 0.01$

$$
=e^{-d T} N^{\prime}(Z) S T^{\left(\frac{1}{2}\right)} *(0.01)
$$

Where $N^{\prime}=$ normal density function

Following the literature on the underpricing and discounting of SEOs (e.g. Altinkiliç and Hansen, 2003; Corwin, 2003; Kim and Park, 2005; Mola and Loughran, 2004), we use the following control variables in our regressions. BETA is the relative risk of a firm's equity compated to the market as a whole, which is computed by regressing monthly returns on the value weighted market returns over the rolling 24-month window ending one month before the offer date. MB is the firm market-to bookratio which is computed as the value of total assets minus the value of book equity plus the market value of equity, divided by total assets. VOLATILITY is the firm stock return volatility which is the standard deviation of stock returns over 30-trading days ending 10 days before the offer date. PRECAR is the pre-SEO share price run-up which is the cumulative market-adjusted return over the period from the filing date to the day before the offer date. SEOPROCEEDS is the relative size of the SEO proceeds which is defined as the value of SEO proceeds divided by the firm market value of equity. TICK is a dummy variable that taking the value of 1 if the decimal portion of the closing price on the day before the offer is less than 0.25 , and zero otherwise. $L N P R I C E$ is the natural logarithm of the closing stock price one day before the offer date. URANK is the underwriter's reputation. We obtain the ranking list of underwriters for our sample firms from Prof. Ritter's underwriter ranking database (https://site.warrington.ufl.edu/ritter/ipo-data/). Table 1 provides variable definitions and more details of each variable construction.

We use the following estimation model to test the effect of CSR and firm-related wealth as well as executive compensation structure on the post-SEO stock return performance.

$$
\begin{aligned}
\text { CARSEO }_{i, t} & =\beta_{0}+\beta_{1} \text { TCSR }_{i, t}+\beta_{2} \text { INSIDEWEALTH }_{i, t} \\
& +\beta_{3} \text { BETA }_{i, t}+\beta_{4} \text { MB }_{i, t}+\beta_{5} \text { VOLATILITY }_{i, t} \\
& +\beta_{6} \text { SEOPROCEEDS }_{i, t}+\beta_{7} \text { FIRMSIZE }_{i, t} \\
& +\beta_{8} \text { URANK }_{i, t}+\varepsilon_{i, t} \\
\text { CARSEO }_{i, t}= & \beta_{0}+\beta_{1} \text { TCSR }_{i, t}+\beta_{2} \text { DELTA }_{i, t}+\beta_{3} \text { VEGA }_{i, t} \\
& +\beta_{4} \text { BETA }_{i, t}+\beta_{5} \text { MB }_{i, t}+\beta_{6} \text { VOLATILITY Y }_{i, t} \\
& +\beta_{7} \text { SEOPROCEEDS }_{i, t}+\beta_{8} \text { FIRMSIZE }_{i, t} \\
& +\beta_{9} \operatorname{URANK}_{i, t}+\varepsilon_{i, t}
\end{aligned}
$$

Prior studies of (Altinkiliç and Hansen, 2003; Corwin, 2003, Kim and Park, 2005) show that outside investors incorporate a discount in the price of new offers to reflect the cost of uncertainty about firm value. The higher level of information asymmetry, the higher degree of SEO discount because it becomes more difficult for both the underwriter and future shareholders to value the issuer. To test our second hypothesis, we construct a dependent variable (SEODISCOUNT) that measures the level of the SEO discount. SEODISCOUNT equals the closing price on the day before the offer minus the offer price, divided by the closing price on the day before the offer.

To test our second hypothesis, we establish the following regression models using SEODISCOUNT as a 
Table 1: Variable Definition and Construction

\begin{tabular}{|c|c|}
\hline TCSR1 & $\begin{array}{l}\text { TCSR1 score is measured as total strength minus total concern in MSCI ESG KLD's five rating } \\
\text { categories }\end{array}$ \\
\hline TCSR2 & $\begin{array}{l}\text { TCSR2 is similarly to TCSR } 1 \text { but excluding corporate governance to disentangle the effect of CSR } \\
\text { and corporate governance. The TCSR } 1 \text { and TCSR } 2 \text { are the equally-weighted average of five (four) } \\
\text { rating categories for the focal firm for every year in our panel dataset. }\end{array}$ \\
\hline SEODISCOUNT & The ratio between the closing price on the offer day minus the offer price, divided by the offer price \\
\hline CARSEO & $\begin{array}{l}\text { The cumulative abnormal stock returns five trading days after the SEO annoucement date } \\
\text { (CAR[0;5]) }\end{array}$ \\
\hline FIRMSIZE & Firm size, measured as the natural logarithm of the market value of common stock \\
\hline SEOPROCEEDS & The number of shares offered divided by the total number of shares outstanding prior to the offer \\
\hline INSIDEWEALTH & $\begin{array}{l}\text { The value of all top executives' stock and options portfolio for a given issuing firm during the offer } \\
\text { year which is reported in the Execucomp database }\end{array}$ \\
\hline DELTA & $\begin{array}{l}\text { The change in executive wealth (dollar value) associated with a one percent change in the firm's } \\
\text { stock price }\end{array}$ \\
\hline VEGA & $\begin{array}{l}\text { The change in executive wealth (dollar value) associated with a one percent change in the standard } \\
\text { deviation of the firm's stock return }\end{array}$ \\
\hline PRECAR & $\begin{array}{l}\text { Cumulative market-adjusted return over the period from the filing date and one day before the official } \\
\text { issue date }\end{array}$ \\
\hline MB & $\begin{array}{l}\text { Market-to-book ratio, defined as total assets minus book equity plus market equity, divided by total } \\
\text { assets }\end{array}$ \\
\hline BETA & $\begin{array}{l}\text { firm beta, computed from a regression of firms' monthly raw returns on the monthly value-weighted } \\
\text { market returns over the rolling five-year window ending in the current fiscal year of the offer date }\end{array}$ \\
\hline VOLATILITY & The standard deviation of stock returns over 30 trading days ending 10 days prior to the offer \\
\hline $\begin{array}{l}\text { IPOUNDER } \\
\text { PRICING }\end{array}$ & $\begin{array}{l}\text { The average underpricing across all IPOs during the same month as the SEO, where the monthly } \\
\text { underpricing estimates for IPOs are obtained from Jay Ritter's website }\end{array}$ \\
\hline OFFERSIZE & Shares offered divided by the total number of shares outstanding prior to the offer \\
\hline TICK & $\begin{array}{l}\text { The dummy variable that equals } 1 \text { if the decimal portion of the closing price one day before the offer } \\
\text { is less than } 0.2 \text { and } 0 \text { otherwise }\end{array}$ \\
\hline LNPRICE & The natural logarithm of the closing stock price one day before the offer date \\
\hline URANK & Underwriter's ranking, we obtain underwriter ranking from Jay Ritter's website \\
\hline NASDAQ & A dummy variable that takes the value of 1 if a firm's stock is traded on NASDAQ and zero otherwise \\
\hline
\end{tabular}

dependent variable and two main independent variables of interest proxied for CSR and executive firm-related wealth: TCSR and INSIDEWEALTH. Based on the previous SEO discounting literature, we also control firm risk $(B E T A)$, market to book ratio $(M B)$, stock return volatility (VOLATILITY), relative offer size (SEOPROCEEDS), preSEO price-run up (PRECAR), firm size (FIRMSIZE), IPO underpricing (IPOUNDERPRICING), and underwriters' reputation ( $U R A N K)$, and a dummy variable for firms listed on Nasdaq stock exchange (NASDAQ) in model (3). We add two other independent variables of interest, namely DELTA and VEGA to examine whether the executive compensation structure impacts the SEO discount in model (4).
$S_{E O D I S C O U N T}{ }_{i, t}=\beta_{0}+\beta_{1}$ TCSR $_{i, t}+\beta_{2}$ BETA $_{i, t}+\beta_{3} M B_{i, t}$ $+\beta_{4}$ VOLATILITY $_{i, t}+\beta_{5}$ PRECAR $_{i, t}+\beta_{6}$ SEOPROCEEDS $_{i, t}$ $+\beta_{7}$ FIRMSIZE $_{i, t}+\beta_{8}$ IPOUNDERPRICING $_{i, t}+\beta_{8}$ TICK $_{i, t}$

$+\beta_{9} L_{N P R I C E}+\beta_{10} U R A N K_{i, t}+\beta_{11} N A S D A Q_{i, t}+\varepsilon_{i, t}$

$S_{\text {SODISCOUNT }}=\beta_{0}+\beta_{1}$ TCSR $_{i, t}+\beta_{2}$ INSIDEWEALTH $_{i, t}$ $+\beta_{3}$ TCSR $^{*}$ INSIDEWEALTH ${ }_{i, t}+\beta_{4}$ DELTA $_{i, t}+\beta_{5}$ VEGA $_{i, t}$ $+\beta_{6}$ BETA $_{i, t}+\beta_{7}$ MB $_{i, t}+\beta_{8}$ VOLATILITY $_{i, t}+\beta_{9}$ PRECAR $_{i, t}$ $+\beta_{10}$ SEOPROCEEDS $_{i, t}+\beta_{11}$ FIRMSIZE $_{i, t}$ $+\beta_{12}$ IPOUNDERPRICING $_{i, t}+\beta_{13}$ URANK $_{i, t}+\beta_{14} N A S D A Q_{i, t}$ $+\varepsilon_{i, t}$ 


\section{Empirical Results}

\subsection{Descriptive Statistics}

Table 2 presents sample selection and descriptive statistics for our sample. The mean (median) of SEO discount the sample is $3.59 \%(2.47 \%)$. The average market-to-book ratio and the firm beta of the sample firms are 3.21 and 1.23 , respectively. The mean of the TCSR 1 score is positive (0.669) which is consistent with prior studies. The mean (median) of FIRMSIZE is $\$ 13.87$ million (\$13.71 million) and the mean (median) of SEOPROCEEDS is 14.13 percent (12.69 percent).

Table 3 presents a Pearson correlation matrix among variables. With few exceptions such as the correlation between TCSR 1 and the firm beta, the correlation between TCSR and $M B$, most pairwise correlations are statistically significant at the 5 or 1 percent levels. The correlation coefficient between TCSR 1 and INSIDEWEALTH is positive and statistically significant indicates that the two variables interact incorporate social activity consideration, consistent with our hypothesis. While the INSIDEWEALTH, VEGA,
DELTA are associated with the total CSR score, the SEO discount is negatively correlated with the total CSR score. These correlations imply that the high CSR firms tend to have high levels of their executive firm related wealth, a higher proportion of equity-based compensation. Also, Table 3 suggests that multicollinearity is not a main concern in our regression analysis.

\subsection{Regression Results}

\subsubsection{The Effects of CSR and Firm-Related Wealth on the Post-SEO Stock Performance}

We first examine whether corporate social activity and executive firm related wealth are associate with the post-SEO stock performance. Table 4 panel A presents the regression results of regressing the firms' post-SEO stock performance on the corporate social responsibility score (TCSR), executive firm-related wealth (INSIDEWEALTH), and other control variables for the sample of SEOs between the period 1991-2015.

Table 2: Sample Selection and Descriptive Statistics

Panel A: Sample Selection Process

\begin{tabular}{|l|c|}
\hline & Observations (N) \\
\hline Number of SEOs of non-financial and utility firms in the sample period 1991-2015 & 3,070 \\
\hline Sample after matching to the KLD database to obtain CSR information & 2,492 \\
\hline Sample after matching to the Ritter's underwriter rank dataset & 2,346 \\
\hline Sample after matching to CRSP/Compustat datasets to compute independent variables & 2,102 \\
\hline Sample after matching to executive compensation from Execucomp dataset & 1,145 \\
\hline Sample with non-missing CEO Delta and Vega information & 978 \\
\hline
\end{tabular}

Panel B: Descriptive Statistics

\begin{tabular}{|l|c|c|c|c|c|}
\hline \multicolumn{1}{|c|}{ Variable } & Mean & Std. & $\mathbf{2 5 \%}$ & Median & $\mathbf{7 5 \%}$ \\
\hline TCSR1 & 0.6696 & 1.7019 & -2.0000 & -1.000 & 0.0000 \\
\hline SEODISCOUNT & 0.0359 & 0.0363 & 0.0008 & 0.0247 & 0.0508 \\
\hline FIRMSIZE & 13.873 & 1.2552 & 12.905 & 13.7158 & 14.657 \\
\hline MB & 3.2126 & 2.8546 & 1.2725 & 2.1167 & 3.9725 \\
\hline FIRMBETA & 1.2328 & 0.9611 & 0.4562 & 1.0834 & 1.8551 \\
\hline VOLATILITY & 0.0307 & 0.0154 & 0.0191 & 0.0266 & 0.0383 \\
\hline IPOUNDERPRICING & 0.0123 & 0.0797 & 0.0671 & 0.1170 & 0.1690 \\
\hline SEOPROCEEDS & 0.1413 & 0.0839 & 0.0744 & 0.1269 & 0.1898 \\
\hline URANK & 8.3862 & 0.9053 & 8.000 & 9.000 & 9.000 \\
\hline LNVEGA & 4.5877 & 1.4968 & 3.6333 & 4.6631 & 5.5754 \\
\hline LNDELTA & 5.2008 & 1.5514 & 4.2916 & 5.3595 & 6.3023 \\
\hline
\end{tabular}


Table 3: Pearson Correlation Matrix

\begin{tabular}{|c|c|c|c|c|c|c|c|}
\hline No. & Variable & 1 & 2 & 3 & 4 & 5 & 6 \\
\hline 1 & TSCR & 1.000 & $-0.048^{* *}$ & $0.1044^{* *}$ & $0.0002^{* *}$ & 0.0008 & 0.0276 \\
\hline 2 & DISCOUNT & $-0.0486^{* *}$ & 1.0000 & $-0.2950^{* *}$ & $0.0329^{* *}$ & $0.1868^{* *}$ & $0.3538^{* *}$ \\
\hline 3 & FIRMSIZE & $0.1044^{* \star *}$ & -0.2950 & 1.0000 & -0.0873 & -0.1329 & -0.2728 \\
\hline 4 & $\mathrm{MB}$ & 0.0002 & $0.0329^{* *}$ & $-0.0873^{* *}$ & 1.0000 & $0.0970^{* * *}$ & $0.0899^{* * *}$ \\
\hline 5 & FIRMBETA & 0.0008 & $0.1868^{* * *}$ & $-0.1329^{* * *}$ & $0.0970^{* * *}$ & 1.0000 & $0.3334^{* * *}$ \\
\hline 6 & VOLATILILTY & 0.0276 & $0.3538^{* * *}$ & $-0.2728^{* * *}$ & 0.0899 & $0.3334^{* * *}$ & 1.0000 \\
\hline 7 & PRECAR & $-0.0434^{* *}$ & $0.0936^{* * *}$ & 0.0223 & 0.0211 & $0.0563^{* * *}$ & $0.0535^{\star * *}$ \\
\hline 8 & OFFERSIZE & $-0.0419^{* * *}$ & $0.1055^{\star * *}$ & -0.4799 & $-0.0779^{* *}$ & $0.0580^{* * *}$ & $0.1957^{* * *}$ \\
\hline 9 & URANK & 0.0050 & $-0.2060^{* * *}$ & $0.4115^{\star \star *}$ & $0.0134^{* * *}$ & $0.0051^{* * *}$ & $-0.0974^{* * *}$ \\
\hline 10 & VEGA & $0.1236^{* *}$ & $-0.1107^{* * *}$ & $0.5671^{* \star *}$ & $0.0842^{* * *}$ & $-0.0661^{* * *}$ & $-0.0413^{* * *}$ \\
\hline 11 & DELTA & $0.0684^{* *}$ & $-0.1570^{* * *}$ & $0.4819^{* * *}$ & $0.2302^{* * *}$ & $-0.0215^{* * *}$ & $-0.0796^{* * *}$ \\
\hline 12 & INSIDEWEALTH & $0.0216^{* * *}$ & $-0.2341^{* * *}$ & $0.2701^{* * *}$ & $0.3015^{* * *}$ & -0.0239 & $-0.1782^{* * *}$ \\
\hline No. & Variable & 7 & 8 & 9 & 10 & 11 & 12 \\
\hline 1 & TSCR & $-0.0434^{* *}$ & $-0.0419^{* * *}$ & 0.0050 & 0.1236 & 0.0684 & $0.02165^{\star * *}$ \\
\hline 2 & DISCOUNT & $0.0936^{* *}$ & $0.1055^{\star * *}$ & $-0.2060^{* *}$ & -0.1107 & -0.1570 & $-0.23415^{* * *}$ \\
\hline 3 & FIRMSIZE & 0.0223 & $-0.4799^{* * *}$ & $0.4115^{* * *}$ & 0.5671 & 0.4819 & $0.2701^{* * *}$ \\
\hline 4 & $\mathrm{MB}$ & $0.0211^{*}$ & $-0.0779^{* * *}$ & 0.0134 & 0.0842 & 0.2302 & $0.3015^{\star * *}$ \\
\hline 5 & FIRMBETA & $0.0563^{* * *}$ & $0.0580^{* * *}$ & 0.0051 & -0.0661 & -0.0215 & -0.0239 \\
\hline 6 & VOLATILILTY & $0.0535^{* * *}$ & $0.1957^{* * *}$ & $-0.0974^{* * *}$ & -0.0413 & -0.0796 & $-0.1782^{* *}$ \\
\hline 7 & PRECAR & 1.0000 & $-0.0732^{* * *}$ & $0.0220^{* * *}$ & -0.0285 & -0.0479 & 0.0227 \\
\hline 8 & OFFERSIZE & $-0.0732^{* * *}$ & 1.0000 & $-0.1019^{* * *}$ & -0.3040 & -0.2607 & $-0.2144^{* * *}$ \\
\hline 9 & URANK & 0.0220 & $-0.1019^{* \star *}$ & 1.0000 & 0.1981 & 0.1441 & $0.0779^{* * *}$ \\
\hline 10 & VEGA & $-0.0285^{* * *}$ & $-0.3040^{* * *}$ & $0.1981^{* * *}$ & 1.0000 & 0.5879 & $0.3408^{* * *}$ \\
\hline 11 & DELTA & $-0.0479^{* * *}$ & -0.2607 & $0.1441^{* * *}$ & $0.5879^{* \star *}$ & 1.0000 & $0.5273^{* * *}$ \\
\hline 12 & INSIDEWEALTH & $0.0227^{* * *}$ & -0.2144 & $0.0779^{* * *}$ & $0.3408^{* * *}$ & $0.5273^{* *}$ & 1.0000 \\
\hline
\end{tabular}

Note: Refer to Table 1 for variable construction and definition. ${ }^{*},{ }^{* *}$, and ${ }^{* *}$ indicates the estimated coefficient is statistically significant at the 10 percent, 5 percent, and 1 percent levels, respectively.

We include calendar year and industry dummy dummy variables as controls for the calendar year and industry fixed effects. Consistent with our hypothesis, corporate social activity $(T C S R)$ and managers' firm related wealth (INSIDEWEALTH) are positively associated with the postSEO stock performance. Specifically, the coefficients on TCSRI and INSIDEWEALTH in column 1 are 0.0029 $(p$-value $<0.01)$ and $0.0042(p$-value $<0.01)$ are statistically significant at the one percent, respectively. Similarly, in column 2 the coefficients on the second proxy for CSR (TCSR2) and INSIDEWEALTH are also positive and statistically significant. As expected, the coefficients on other control variables are consistent with the literature on the determinants of the post-SEO stock performance.
For example, the coefficient on VOLATILITY is -0.6992 ( $p$-value $<0.01$ ), indicating that the greater the price volatility, the lower the post-SEO stock return performance.

In Table 4 panel B, we present the results for our equation (2) regressions. Instead of using INSIDEWEALTH along with TCSR as the main exploratory variables of interest, we use two measures of pay-performance sensitivity, namely DELTA and VEGA in our OLS regressions. The results show that while the coefficients on DELTA $(0.0028$, $p$-value $<0.05$ in model 1 and 0.027, p-value $<0.01$ in model 2) are positive and significant, the coefficients on VEGA are negative, but not statistically significant. The results provide evidence that managers with a high proportion of equity in their compensation package are associated with high CSR 
Table 4: Effects of The Executive Firm Related Wealth and Executive Pay-Performance Sensitivity on the Post-SEO Stock Performance

Panel A: Effects of The Executive Firm Related Wealth on the Post-SEO Stock Performance

\begin{tabular}{|l|c|c|}
\hline \multirow{2}{*}{\multicolumn{1}{|c|}{ Variables }} & \multicolumn{2}{c|}{ Dependent Variable (CARSEO) } \\
\cline { 2 - 3 } & TCSR1 & TCSR2 \\
\cline { 2 - 3 } & $\mathbf{( 1 )}$ & $\mathbf{( 2 )}$ \\
\hline Intercept & 0.0136 & 0.0658 \\
\hline TCSR & $0.0029^{* * *}$ & $0.0025^{* *}$ \\
\hline INSIDEWEALTH & $0.0042^{* * *}$ & $0.0041^{* * *}$ \\
\hline BETA & $-0.0046^{*}$ & $0.0051^{*}$ \\
\hline MB & 0.0035 & 0.0060 \\
\hline VOLATILITY & $-0.6992^{* * *}$ & $-0.7006^{* * *}$ \\
\hline SEOPROCCEEDS & -0.0210 & -0.0220 \\
\hline FIRMSIZE & 0.0031 & 0.0027 \\
\hline URANK & $-0.0079^{* * *}$ & $-0.0082^{* * *}$ \\
\hline NASDAQ & $0.0083^{* *}$ & $0.0089^{* *}$ \\
\hline Year Dummies & Yes & Yes \\
\hline Industry Dummies & Yes & Yes \\
\hline Adjusted R2 & $12.60 \%$ & $12.55 \%$ \\
\hline N & 2,102 & 2,102 \\
\hline
\end{tabular}

Panel B: Effects of Executive Pay-Performance Sensitivity on The Post-SEO Stock Performance

\begin{tabular}{|l|c|c|}
\hline \multirow{2}{*}{\multicolumn{1}{|c|}{ Variables }} & \multicolumn{2}{c|}{ Dependent Variable CARSEO } \\
\cline { 2 - 3 } & $\begin{array}{c}\text { Model 1 } \\
\text { TCSR1 }\end{array}$ & $\begin{array}{c}\text { Model 2 } \\
\text { TCSR2 }\end{array}$ \\
\hline Intercept & $0.0527^{* *}$ & $0.0583^{* *}$ \\
\hline TCSR & $0.0312^{* * *}$ & $0.0278^{* * *}$ \\
\hline DELTA & $0.0028^{* * *}$ & $0.0027^{* * *}$ \\
\hline VEGA & -0.0138 & -0.0137 \\
\hline BETA & $-0.0048^{* *}$ & $-0.0055^{* *}$ \\
\hline MB & -0.0094 & -0.0095 \\
\hline VOLATILITY & $-0.7498^{* * *}$ & $-0.7639^{* * *}$ \\
\hline SEOPROCCEEDS & -0.0308 & -0.0314 \\
\hline FIRMSIZE & 0.0013 & 0.00931 \\
\hline URANK & $-0.0827^{* * *}$ & $-0.0107^{* * *}$ \\
\hline NASDAQ & $0.0099^{* *}$ & $0.0107^{* * *}$ \\
\hline Year Dummies & Yes & Yes \\
\hline Industry Dummies & Yes & Yes \\
\hline Adjusted R2 & $13.70 \%$ & $13.20 \%$ \\
\hline N & 978 & 978 \\
\hline
\end{tabular}

Note: Refer to Table 1 for variable construction and definition. *, **, and ${ }^{* * *}$ indicates the estimated coefficient is statistically significant at the 10 percent, 5 percent, and 1 percent levels, respectively. activities. This suggests that managers with a high level of the firm related wealth and high equity-based proportion in their compensation packages are more likely to engage in CSR activities. As a result, coupled with the positive effects of CSR on firm reputation and financial performance, managers can maximize their wealth through the SEO episodes.

Overall, the results from Table 4 supports our hypotheses $\mathrm{H} 1 \mathrm{~A}$ and $\mathrm{H} 1 \mathrm{~B}$, respectively. We find that managers with a higher proportion of equity-based compensation are associated with a high level of CRS activities. We also find some evidence that managers are more likely to engage in CSR activities, especially in the SEO sample firms. The CSR may mitigate the negative market response to new equity issues, thereby reducing the negative effect of the stock dilution on the managers' firm related wealth.

\subsubsection{The Effects of CSR and Firm-Related Wealth on the SEO Discount}

Table 5 reports the results from our regression equation (3) which examines whether CSR has a positive effect on the SEO discount. As shown in the literature, CSR has positive effects on firm reputation and helps reduce investors' perception of the firm performance uncertainty during the issuing periods. We expect that high CSR firms are more likely to experience lower levels of SEO discount because the SEO discount reflects the cost of uncertainty about firm value as well as the underwriters' costs for acquiring information. Table 5 Panel A provides results from a univariate test. We sorted the sample SEO firms into quintiles based on CSR scores (TCSR1 and TCSR2). The top quintile is classified as the High CSR group and the bottom quintile is classified as the Low CSR group. Using both TCSR 1 and TCSR2 measures, we find that new issues of high CSR firms, on average, have a discount of 3.33 (3.25) percent, while those of low CSR firms have a discount of 3.78 (3.66) percent, which is 45 (41) basis points higher.

Table 5 Panel B provides results of our regression of SEODISCOUNT on TCSR and other control variables. Our hypothesis $2 \mathrm{~A}$ suggests that issuing firms with high CSR should experience less SEO discount. Consequently, we test whether, under the presence of CSR activities, underwriters are more willing to set a higher offer price for their client firms, thereby lower the SEO discount. The results reported in Table 5 Panel B support our predictions. The coefficients on TCSR 1 and TCSR 2 are both negative and statistically significant $(-0.0072$ and $-0.0028 ; p$-value $<0.05$ for TCSR1 and TCSR2, respectively). The results suggest that CSR allows underwriters to set higher office prices for new issues, thereby protecting shareholders' wealth from the negative impact of SEO discount on the firm's new equity offerings. 
Table 5: The Effect of CSR on the SEO Discount

Panel A: Univariate Analysis

\begin{tabular}{|l|c|c|}
\hline & $\begin{array}{c}\text { TCSR1 } \\
\text { Measure }\end{array}$ & $\begin{array}{c}\text { TCSR2 } \\
\text { Measure }\end{array}$ \\
\hline $\begin{array}{l}\text { Group 1 } \\
\text { Low CSR Score) }\end{array}$ & 0.0378 & 0.0366 \\
\hline $\begin{array}{l}\text { Group 2 } \\
\text { (High CSR Score) }\end{array}$ & 0.0333 & 0.0325 \\
\hline $\begin{array}{l}\text { Difference } \\
\text { (Group 1 - Group 2) }\end{array}$ & $0.0044^{* *}$ & $0.0041^{* * *}$ \\
\hline$t$-value & 2.14 & 2.24 \\
\hline
\end{tabular}

Panel B: Multivariate Analysis

\begin{tabular}{|l|c|c|}
\hline \multirow{2}{*}{\multicolumn{1}{|c|}{ Variables }} & \multicolumn{2}{c|}{$\begin{array}{c}\text { Dependent Variable } \\
\text { (SEODISCOUNT) }\end{array}$} \\
\cline { 2 - 3 } & TCSR (1) & TCSR2 (2) \\
\hline Intercept & $0.1041^{* * *}$ & $0.1045^{* * *}$ \\
\hline TCSR & $-0.0072^{* *}$ & $-0.0028^{* *}$ \\
\hline BETA & $0.0026^{* * *}$ & $0.0025^{* * *}$ \\
\hline MB & $0.0045^{*}$ & $0.0046^{*}$ \\
\hline VOLATILITY & $0.6672^{* * *}$ & $0.6598^{* * *}$ \\
\hline PRECAR & $0.0245^{* * *}$ & $0.0248^{* * *}$ \\
\hline SEOPROCCEEDS & $0.1517^{*}$ & $0.0153^{*}$ \\
\hline FIRMSIZE & $-0.0042^{* * *}$ & $-0.0043^{* * *}$ \\
\hline IPOUNDERPRICING & $-0.0018^{* * *}$ & $-0.0019^{* *}$ \\
\hline TICK & $0.0102^{* *}$ & $0.0101^{* *}$ \\
\hline LNPRICE & $-0.0246^{* *}$ & $-0.0247^{* *}$ \\
\hline URANK & $-0.0034^{* * *}$ & $-0.0033^{* * *}$ \\
\hline NASDAQ & $0.0021^{* *}$ & $0.0019^{* *}$ \\
\hline Year Dummies & Yes & Yes \\
\hline Industry Dummies & Yes & Yes \\
\hline Adjusted R2 & 0.1986 & 0.1930 \\
\hline N & 2,102 & 2,102 \\
\hline
\end{tabular}

Note: Refer to Table 1 for variable construction and definition. *, **, and ${ }^{* * *}$ indicates the estimated coefficient is statistically significant at the 10 percent, 5 percent, and 1 percent levels, respectively.

To further examine whether the effects of managers' firm related wealth, the sensitivity of executive wealth, and the interaction between the managers' related wealth and $C S R$ on the pricing of the SEOs, we add an interaction term TCSR *INSIDEWEALTH (column 1,2) along with TCSR and INSIDEWEALTH, and VEGA (column 3,4) in our regressions. Table 6 presents the results of our regression estimation of equation (4). The coefficients on TCSR and INSIDEWEALTH are both negative and significant, indicating that TCSR and INSIDEWEALTH are negatively associated with the SEO discount. This implies that underwriters perceived CSR as a firm's value-added activities, thereby rewarding issuing firms with lower SEO discounts.

Table 6 column 3 and 4 also reveal the association between the pay-performance sensitivity with the SEO discount. While the coefficients on DELTA are negative (significant (-0.0071 and -0.0074; $p$-value $<0.01$ for TCSR 1 and TCSR2, respectively) and significant, the coefficients on VEGA are positive and significant (0.0036 and 0.0035; $p$-value $<0.01$ for TCSR 1 and TCSR2, respectively). This is also consistent with our hypothesis that the executive's portfolio sensitivities to changes in stock prices (DELTA) have positive a effect on the SEO discount. A negative effect of $V E G A$ on the SEO discount suggests that underwriters in the anticipation of risk-taking behaviors of managers with large vegas are more likely to set lower offer prices because of a higher level of price uncertainty of issuing firms. Taken together, these findings show that CSR attenuates the negative effects of information asymmetry and price uncertainty of issuing firms, thereby reducing the SEO discounts of their new equity offerings. The results confirm our $\mathrm{H} 2 \mathrm{~A}$ and $\mathrm{H} 2 \mathrm{~B}$ by consistently finding consistent negative coefficients of TCSR, INSIDEWEALTH, and a positive coefficient $V E G A$ across all model specifications. Other coefficients on control variables such as PRECAR, URANK, SEOPROCEEDS, MB, TICK, LNPRICE are all statistically significant and their signs of coefficients are in line with previous studies.

\section{Conclusion}

In this study, we analyze the roles of CSR and executive compensation structure on the pricing of seasoned equity offerings. Specifically, we examine the role of CSR in reducing the level of information asymmetry between managers and future shareholders of issuing firms through seasoned equity offerings. More importantly, we investigate the interaction between executive compensation structure and CSR on the SEO discount. Consistent with prior studies, we confirm that CSR attenuates the impact of information asymmetry and price uncertainty on the pricing of the offers and hence the SEO discount. We show that CSR reinforces the impact of managers' firm related wealth on the pricing of seasoned equity offerings. We find a positive association between CSR and issuing firms with managers with a high proportion of equity-based compensation.

In summary, CSR activities and executive compensation structure have significant effects on the SEO discount. Underwriters reward high CSR issuing firms with a lower degree of SEO discount through the underwriting process 
Table 6: The Effects of CSR and Executive Firm Related Wealth on The SEO Discount

\begin{tabular}{|c|c|c|c|c|}
\hline \multirow{3}{*}{ Variables } & \multicolumn{2}{|c|}{$\begin{array}{c}\text { Dependent Variable SEODISCOUNT } \\
\text { Equation (3) }\end{array}$} & \multicolumn{2}{|c|}{$\begin{array}{c}\text { Dependent Variable SEODISCOUNT } \\
\text { Equation (4) }\end{array}$} \\
\hline & $\begin{array}{c}\text { TCSR1 } \\
\text { Measure }\end{array}$ & $\begin{array}{c}\text { TCSR2 } \\
\text { Measure }\end{array}$ & $\begin{array}{c}\text { TCSR1 } \\
\text { Measure }\end{array}$ & $\begin{array}{l}\text { TCSR2 } \\
\text { Measure }\end{array}$ \\
\hline & (1) & $(2)$ & (3) & $(4)$ \\
\hline Intercept & $0.0656^{* * *}$ & $0.0673^{* * *}$ & & $0.0638^{\star *}$ \\
\hline TCSR & $-0.0043^{\star *}$ & $-0.0041^{* *}$ & $-0.0387^{\star *}$ & $-0.0067^{\star *}$ \\
\hline INSIDEWEALTH & $-0.0029^{* * *}$ & $-0.0029^{* * *}$ & & \\
\hline TCSR*INSIDEWEALTH & $0.0045^{\star \star}$ & $0.0048^{* *}$ & & \\
\hline$D E L T A$ & & & $-0.0071^{* * *}$ & $-0.0074^{* * *}$ \\
\hline VEGA & & & $0.0036^{* * *}$ & $0.0035^{* * *}$ \\
\hline BETA & 0.0983 & 0.0010 & $0.0018^{*}$ & $0.017^{*}$ \\
\hline$M B$ & $-0.01356^{* *}$ & $0.0159^{* *}$ & $0.0038^{* *}$ & $0.0036^{* *}$ \\
\hline VOLATILITY & $0.6701^{* * *}$ & $0.6671^{* * *}$ & $0.6713^{* * *}$ & $0.6695^{\star * *}$ \\
\hline PRECAR & $0.0249^{* * *}$ & $0.0246^{* * *}$ & $0.0189^{* *}$ & $0.0188^{* * *}$ \\
\hline SEOPROCCEEDS & $0.0098^{*}$ & $0.0107^{*}$ & $0.0167^{*}$ & $0.0011^{*}$ \\
\hline FIRMSIZE & -0.0036 & -0.0045 & -0.0458 & -0.0019 \\
\hline URANK & $-0.0029^{* *}$ & $-0.0028^{* *}$ & $-0.0337^{* * *}$ & $-0.0034^{* * *}$ \\
\hline TICK & $0.0080^{* * *}$ & $0.0081^{* *}$ & $0.0083^{* * *}$ & $0.0814^{* *}$ \\
\hline LNPRICE & $-0.0182^{* *}$ & $-0.0184^{* *}$ & $-0.0183^{* *}$ & $-0.0185^{\star *}$ \\
\hline NASDAQ & $0.0041^{* *}$ & $0.0038^{* *}$ & $0.0021^{* *}$ & $0.0018^{* *}$ \\
\hline Year Dummies & Yes & Yes & Yes & Yes \\
\hline Industry Dummies & Yes & Yes & Yes & Yes \\
\hline Adjusted R2 & 0.1810 & 0.1809 & 0.2155 & 0.2152 \\
\hline $\mathrm{N}$ & 978 & 978 & 978 & 978 \\
\hline
\end{tabular}

Note: Refer to Table 1 for variable construction and definition. *,**, and *** indicates the estimated coefficient is statistically significant at the 10 percent, 5 percent, and 1 percent levels, respectively.

because CSR helps reduce the price uncertainty of issuing as well as the costs of acquiring information, thus reducing the information asymmetry between managers and outside investors. In addition, the executive compensation structure also has a pronounced effect on the issuing firms' post-SEO performance and the SEO discount. In short, managers with a high level of pay-performance sensitivity, especially those with a high proportion of equity-based compensation. Overall, our study extends the literature in several ways. First, this is the first study examining the effect of CSR on the pricing of seasoned equity offerings. Second, we provide new evidence that pay performance-sensitivity affects the pricing of new offers. Our study also sheds light on the underwriters' assessment of the role of CSR in reducing information asymmetry and the pre-SEO price uncertainty of issuing firms

\section{References}

Altinkiliç, O., \& Hansen, R. S. (2003). Discounting and underpricing in seasoned equity offers. Journal of Financial Economics, 69(2), 285-323. https://doi.org/10.1016/S0304405X(03)00114-4

Black, F., \& Scholes, M. (1973). The pricing of options and corporate liabilities. Journal of Political Economy, 81(3), 637-654. https://doi.org/10.1086/260062

Brazel, J. F., \& Webb, E. (2006). CEO compensation and the seasoned equity offering decision. Managerial and Decision Economics, 27, 363-378. https://doi.org/10.1002/mde.1268

Brisker, E. R., Autore, D. M., Colak, G., \& Peterson, D. R. (2014). Executive compensation structure and the motivations for seasoned equity offerings. Journal of Banking and Finance, 40, 330-345. https://doi.org/10.1016/j.jbankfin.2013.12.003 
Carlson, M., Fisher, A., \& Giammarino, R. (2010). SEO risk dynamics. Review of Financial Studies, 23, 4026-4077. https:// doi.org/10.1093/rfs/hhq083

Chatterji, A. K., Levine, D. I., \& Toffel, M. W. (2009). How well do social ratings actually measure corporate social responsibility? Journal of Economics and Management Strategy, 18(1), 125-169. https://doi.org/10.1111/j.1530-9134.2009.00210.x

Core, J., \& Guay, W. (2002). Estimating the value of employee stock option portfolios and their sensitivities to price and volatility. Journal of Accounting Research, 40(3),613-630. https://doi. org/10.1111/1475-679X.00064

Corwin, S. A. (2003). The determinants of underpricing for seasoned equity offers. Journal of Finance, 48(5), 2249-2279. https://doi.org/10.1111/1540-6261.00604

Datta, S., Iskandar-Datta, M., \& Raman, K. (2005). Executive compensation structure and corporate equity financing decisions. Journal of Business, University of Chicago Press, 78(5), 1859-1890. https://doi.org/10.1086/431445

Edmans, A. (2011). Does the stock market fully value intangibles? Employee satisfaction and equity prices. Journal of Financial Economics, 101(3), 621-640. https://doi.org/10.1016/j. jfineco.2011.03.021

Feng, Z. Y., Chen, C. R., \& Tseng, Y. J. (2018). Do capital markets value corporate social responsibility? Evidence from seasoned equity offerings. Journal of Banking and Finance. 94(C), 54-74. https://doi.org/10.1016/j.jbankfin.2018.06.015

Jensen, M. C., \& Meckling, W. H. (1976). Theory of the firm: Managerial behavior, agency costs and ownership structure. Journal of Financial Economics, 3(4), 305-360. https://doi. org/10.1016/0304-405X(76)90026-X

Kim, Y., \& Park, M. S. (2005). Pricing of seasoned equity offers and earnings management. Journal of Financial and Quantitative Analysis, 40(2), 435-463. https://doi.org/10.1017/ s0022109000002374
Kim, Y., Park, M. S., \& Wier, B. (2012). Is earnings quality associated with corporate social responsibility? Accounting Review, 87(3), 761-796. https://doi.org/10.2308/accr-10209

Lins, K. V., Servaes, H., \& Tamayo, A. (2017). Social Capital, Trust, and Firm Performance: The Value of Corporate Social Responsibility during the Financial Crisis. Journal of Finance, 72(4), 1785-1824. https://doi.org/10.1111/jofi.12505

Mola, S., \& Loughran, T. (2004). Discounting and Clustering in Seasoned Equity Offering Prices. Journal of Financial and Quantitative Analysis, 39(01), 1-23. https://doi.org/10.1017/ S0022109000003860

Myers, S. C., \& Majluf, N. S. (1984). Corporate financing and investment decisions when firms have information that investors do not have. Journal of Financial Economics, 13(2), 187-221. https://doi.org/10.1016/0304-405X(84)90023-0

Sundaram, R. K., \& Yermack, D. L. (2007). Pay me later: Inside debt and its role in managerial compensation. Journal of Finance, 62(4), 1551-1588. https://doi.org/10.1111/j.15406261.2007.01251.x

Yang, H. C., \& Kim, Y. E. (2018). The effects of corporate social responsibility on job performance: Moderating effects of authentic leadership and meaningfulness of work. Journal of Asian Finance, Economics and Business, 5(3), 121-132. https://doi.org/10.13106/jafeb.2018.vol5.no3.121

Yoon, B., \& Lee, J. H. (2019). Corporate social responsibility and information asymmetry in the Korean market: Implications of chaebol affiliates. Journal of Asian Finance, Economics and Business, 6(1), 21-31. https://doi.org/10.13106/jafeb.2019. vol6.no1.21

Zahari, A. R., Esa, E., Rajadurai, J., Azizan, N. A., \& Tamyez, P. F. M. (2020). The effect of corporate social responsibility practices on brand equity: An examination of malaysia's top 100 brands. Journal of Asian Finance, Economics and Business, 7(2), 271-280. https://doi.org/10.13106/jafeb.2020.vol7.no2.271 